\title{
Variations of Wave Energy Power in Shoaling Zone of Benin Coastal Zone
}

\author{
Mathias A. Houékpohéha (1),(2),(*); Basile B. Kounouhéwa(3),(2); Joël T. Hounsou (1) ; \\ Bernard N. Tokpohozin(1),(2); Jean V. Hounguèvou(1) and Cossi. N. Awanou(3)
}

(1) Institut de Mathématiques et de Sciences Physiques (IMSP/UAC) 01BP 613 Porto- Novo

(2) Centre Béninois de la Recherche Scientifique et Technique (CBRST) 03BP 1665 Cotonou

(3) Laboratoire de Physique du Rayonnement FAST-UAC 01BP 526 Cotonou Rép. du Bénin

\begin{abstract}
Today, we observe at the population level, that the improvement in comfort is accompanied by an increase in the electrical energy required. The predicted exhaustion of fossil energy resources maintains some speculation. Their unequal geographical distribution justifies the energy dependence of Benin overlooked from outside. So it is urgent to explore the various sources of renewable energy available to Benin. In this work, using measurements made by the Millennium Challenge Account (MCA-Benin) as part of the extension of the port of Cotonou, with Boussinesq equations (Peregrine) and Stokes waves dispersion relation, we characterized the variations of various swell parameters (height, wavelength, velocities) in the shoaling zone on the study site and proceeded to estimate variations in wave energy power from deep waters to the bathymetric breaking point. Finally, the zone with high energy power (where the conversion of this energy into electrical energy would be profitable) of these waves is highlighted on the site, the local water depth at the point of breaking waves is evaluated and results obtained allowed to justify the very energetic character take by these swells on this coast when they are close to the beach.
\end{abstract}

Keywords: wave energy power; weakly nonlinear waves; Benin coastal zone; wave shoaling; nonlinear Boussinesq equations

Article History : Received November 2, 2014 ; Received in revised form January 4, 2015; Accepted February 3, 2015; Available online

How to Cite This Article: Houékpohéha M. A.,. Kounouhéwa B. B., Hounsou J. T., Tokpohozin B. N, Hounguèvou J. V., and Awanou C. N. (2015). Variations of Wave Energy Power in Shoaling Zone of Benin Coastal Zone. Int. Journal of Renewable Energy Development, 4(1), 64-71. http://dx.doi.org/10.14710/ijred.4.1.64-71

\section{Introduction}

The description of the ocean, fluid medium, heterogeneous, turbulent, headquarters of numerous interactions at different scales of time and space, is not accessible without a dual approach of geographical exploration and scientific understanding. It is even more complex when the swell is influenced by the seabed that causes the amplification of its height and the contraction of its wavelength in the coastal areas (Babarit, 2009; Battjes, 2004). These variations of the different swell parameters imply variations in its energetic power depending on the nature and the slope of the seabed.

Benin energy situation is characterized by low access to electricity and almost total dependence on outside electrical energy rates. Coastal nation of Gulf of Guinea, it benefits to the south the access to the ocean for a distance of $125 \mathrm{~km}$ approximately (Houékpohéha et al., 2014). On this side, the almost permanent propagation of regular waves is observed. To ensure energy independence, the exploration of all available sources of renewable energy is essential. An advantageous solution to fight against coastal erosion in Benin and the sub-region is the transformation of wave energy into electrical energy (Kounouhéwa et al., 2014). To this end, highly accurate and consistent characterization of this energy resource is crucial in order to identify areas of high energy output.

In the course of its propagation approaching the coast, swell undergoes the modifications related to the depth of decreasing and coastal morphology (Barthe at al., 1989). When the wave approaches the coast, it undergoes deformations according to schematic evolution below (Figure 1) (Astier, 2014): at the same 
Citation: Houékpohéha M. A., Kounouhéwa B. B., Hounsou J. T., Tokpohozin B. N, Hounguèvou J. V., and Awanou C. N. (2015). Variations of Wave Energy Power in Shoaling Zone of Benin Coastal Zone. Int. Journal of Renewable Energy Development, 4(1), 64-71, doi:10.14710/ijred.4.1.64-71

$\mathrm{P}$ a g e $\mid 65$

time she stiffened, water depth decreases (lifted zone or shoaling zone) to the breaking point associated with intense turbulent motions (breaking zone), then the waves reorganize themselves in the form of propagating hydraulic jump (internal surf zone), which reach the beach by generating run-up (Swash zone) (Bonneton, 2003 and Bird, 1985). In previous work, Bonneton (2003), Panchang (1991) and others have shown that the basic parameters that characterize the swells are their wavelength (L), their period (T), the vertical elevation of the sea surface $(\eta)$ or peak to valley height $(\mathrm{H})$, the phase velocity $\left(\boldsymbol{C}_{\boldsymbol{\varphi}}\right)$ and the group velocity $\left(\boldsymbol{C}_{\boldsymbol{g}}\right)$ of wave (Bonneton et al., 2001) and (Panchang et al., 1991).

The coastal zone where the swell feels the perturbation effect of the seabed is divided into two areas: the intermediate zone (which is offered the shoaling wave) and the surf and swash zones (Kounouhewa et al., 2014). After identifying, from the measurement data made, the equations that describe the swells in the shoaling zone of the coastal zone of Benin, the objective in this work is to evaluate the variations of parameters that characterize swells, to estimate changes in their energy power in this area and to predict wave height and local water depth at bathymetric breaking point of these swell is performed in order to identify areas of high energy power where the installation of a converter of this energy into electrical energy could be profitable.

\section{Methodology}

\subsection{Presentation of the study site and data used:}

Benin is a country in the Gulf of Guinea between the parallel $6^{\circ} 15^{\prime}$ and $12^{\circ} 30^{\prime}$ north latitude one hand and meridians $1^{\circ}$ and $3^{\circ} 40^{\prime}$ east longitude other hand. It has a coastal area with a length of 125 kilometers from Hilla-Condji in the west to Kraké in the east. Benin's coast is more or less linear and interrupted at two locations, namely: the Mouth of Roy and the mouth of the Cotonou channel.

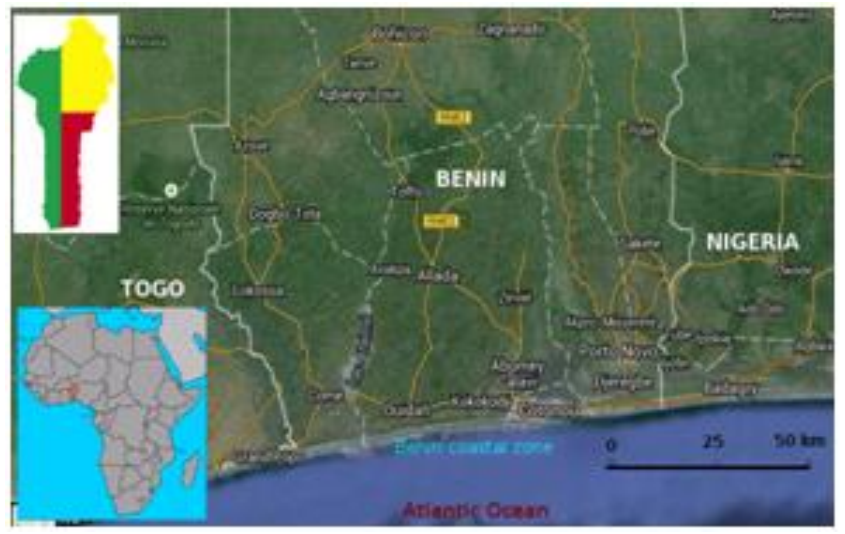

Figure 1. Geographic situation of Benin coastal zone
Benin coastal zone is between $6^{\circ} 15^{\prime}$ and $6^{\circ} 23^{\prime}$ to north latitude. It is part of the coastal sedimentary basin of which the oldest date back to the Cretaceous period lands (the end of the secondary era). The climate is sub-equatorial with two dry seasons and two rainy seasons alternate (Houékpohéha et al., 2014)

This coastal zone, belonging to Gulf of Guinea, receives regular waves of low amplitude. Benin bathymetry and wave power measurements in six months time step of five minutes as part of the extension of the port of Cotonou by the Millennium Challenge Account (MCA-Benin) helped define stable average data on the site of the port of Cotonou.

- In deep waters, the average wave height is $H_{o}=2 a_{o}=0.8 \mathrm{~m}$ and its stable average period $T=12 s$ at a position where the local water depth is approximately $d_{o}=130 \mathrm{~m}$.

- The gravity on the Benin coast is approximately $g=9.79 m \cdot s^{(-2)}$ and wavelength in deep waters is approximately $L_{o}=200 \mathrm{~m}$ (Dégbé et al., 2010)

- On this site, the period of the waves varies between $8 s$ and $18 s$ and its stable average value is $12 s$. This parameter is the only one that remains practically constant during a given wave shoaling. $\left(T \approx T_{o}=c s t\right)$

- The bathymetric map (below) obtained near the IRHOB (Institute of Halieutic and Oceanographic Research of Benin) shows the evolution of local water depth in Benin coastal zone and allowed us to predict the average slope of the seabed

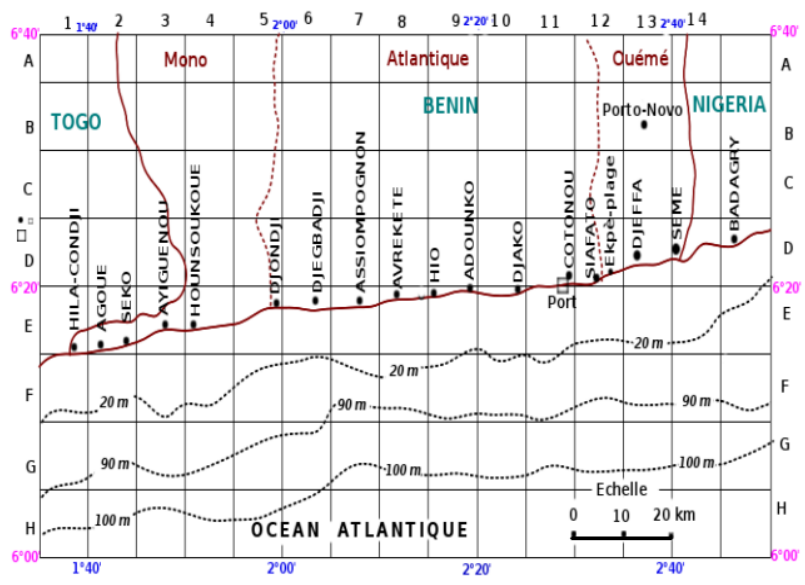

Figure 2. Bathymetric map of Benin seabed

- The seabed in the coastal zone is almost (less irregular) flat and inclined. It is a gently sloping seabed $p=\tan \beta$ such as $0.001<\tan \beta \leq 0.1 \Rightarrow$ $\tan \beta \approx \beta$. The average of the slope in the shoaling zone is $\beta_{m} \approx \frac{100}{20000}=0.05 \quad$ (Kounouhéwa et al., 2014b).

- A series of measurements made on the site shows that the local water depth at the breaking point 
varies between $0.8 \mathrm{~m}$ and $2.7 \mathrm{~m}$ while height at this point is between $1 \mathrm{~m}$ and $2.6 \mathrm{~m}$.

2.2. Variations of wave parameters from deep waters to breaking point

For waves whose wavelength is $\mathrm{L}$, three propagation zones are defined: deep waters when $d \geq \frac{L}{2} \quad$ and shoaling zone if $\frac{L}{25} \leq d \leq d_{b}$ (Kounouhéwa et al., 2014)

The dispersion relation of Airy or Stokes waves is (Kounouhéwa et al., 2014a; Fenton, 1990)

$\omega^{2}=\frac{4 \pi^{2}}{T^{2}}=g k \tanh (k d)$

Expressions reflecting changes in phase velocity $C_{\varphi}$ and group velocity $C_{g}$ are: (Kounouhéwa et al. 2014a; Catalan and al. 2008).

$$
\left\{\begin{array}{l}
C_{\varphi}=\frac{\omega}{k}=\sqrt{\frac{g}{k} \tanh (k d)} \\
C_{g}=\frac{1}{2}\left(1+\frac{2 k d}{\sinh (2 k d)}\right) \sqrt{\frac{g}{k} \tanh (k d)}
\end{array}\right.
$$

In $\quad$ deep $\quad$ waters $\left(d \geq \frac{L_{o}}{2} \Rightarrow \mu \geq \frac{1}{2}\right)$, $\tanh (k d) \approx 1$ then all parameters are constant in this area of propagation and expression of the wavelength, phase and group velocities are:

$L_{o}=\frac{g T^{2}}{2 \pi}$ and $C_{\varphi_{o}}=2 C_{g_{o}}=\frac{g T}{2 \pi}$

In the Gulf of Guinea at Cotonou, the waves are Stokes swells $(\eta \ll d)$, weakly nonlinear $(\varepsilon \ll 1)$ and lowdispersive $\left(\mu^{2}<1\right)$.

In Benin shoaling zone $\left(d_{b} \leq d \leq \frac{L_{o}}{2} \Rightarrow \mu_{b} \leq \mu \leq \frac{1}{2}\right)$, the nonlinearity parameter $\varepsilon=\frac{H}{2 d}$ increase, seabed is nearly flat and Stokes waves become nonlinear. As the local water deep is variable, the wave propagation in $2 \mathrm{D}$ is modeled by the Boussinesq equations (Peregrine): (Chazel, 2007) and (Bellec et al., 2013)

$$
\begin{aligned}
& \left\{\begin{array}{l}
\frac{\partial \eta}{\partial t}+\frac{\partial(d u)}{\partial x}=0 \\
\frac{\partial u}{\partial t}+g \frac{\partial \eta}{\partial x}=\mu^{2}\left[\frac{d}{2} \frac{\partial^{2}}{\partial x^{2}}\left(d \frac{\partial u}{\partial t}\right)-\frac{d^{2}}{6} \frac{\partial^{3} u}{\partial x^{2} \partial t}\right]+\mathcal{O}\left(\mu^{4}\right)
\end{array}\right. \\
& \text { with }\left\{\begin{array}{l}
h=\eta+d \\
u=u(x, t) \\
\eta=\eta(x, t) \\
d=d(x)
\end{array}\right.
\end{aligned}
$$
given by

Vertical elevation $\eta(x, t)$ of ocean free surface is

$\eta(x, t)=\frac{H(x)}{2} e^{i(k x-\omega t+\varphi)}$

Boundary conditions at the border of deep waters and the beginning of shoaling zone where $\mu=$ $\frac{1}{2}$ or $d=\frac{L_{o}}{2}$, are:

$H\left(\mu=\frac{1}{2}\right) \approx \mathrm{H}_{\mathrm{o}}$ and $L\left(\mu=\frac{1}{2}\right) \approx L_{\mathrm{o}}$

The equation of tangent line to the seabed is $z=-d=x \tan \beta$ (Tsai et al., 2002; Zou et al., 2003) with $d=\mu L_{o} \quad$ (Senechal, 2003). On the study site $\tan \beta \approx \beta$, thus:

$d=-\beta x=\mu L_{o}$

Using the relationship (5), (6) and (7) to solve Boussinesq (Peregrine) equations, we obtain in shoaling zone:

$\left\{\begin{array}{l}H=H_{o}\left(\frac{1}{2 \mu}\right)^{1 / 4}=H_{o}\left(\frac{2 d}{L_{o}}\right)^{-1 / 4} \\ L=L_{o}(2 \mu)^{1 / 2}=L_{o}\left(\frac{2 d}{L_{o}}\right)^{1 / 2}\end{array}\right.$

According to this theory, which takes into account the variability of the bathymetry, the different coefficients $\delta_{1}=\frac{C_{\varphi}}{c_{\varphi_{o}}}, \quad \delta_{2}=\frac{C_{g}}{C_{g_{o}}}, \delta=\frac{L}{L_{o}}$ and $K_{s}=\frac{H}{H_{o}}$ respectively show the changes of phase velocity, group velocity, wavelength and height of the swell from deep waters to the bathymetric breaking point.

\subsection{Variations in swell energy power:}

The average of the total energy $E$ per unit length of a swell of which the height is $H$ is expressed: (Ardakani et al., 2010)

$<E>=\frac{1}{8} \rho g H^{2}$

The energy power $P$ per unit length of a wave is the product of its average total energy and its group velocity (Ardakani et al. 2010; Babarit et al. 2009)

$P=<E>. C_{g}$

In deep waters, we have:

$P=<E>_{o} . C_{g_{o}}=\frac{1}{8} \rho g H_{o}^{2} C_{g_{o}}=\frac{1}{32 \pi} \rho g^{2} H_{o}^{2} T$ 
Citation: Houékpohéha M. A., Kounouhéwa B. B., Hounsou J. T., Tokpohozin B. N, Hounguèvou J. V., and Awanou C. N. (2015). Variations of Wave Energy Power in Shoaling Zone of Benin Coastal Zone. Int. Journal of Renewable Energy Development, 4(1), 64-71, doi:10.14710/ijred.4.1.64-71

$\mathrm{P}$ a g e $\mid 67$

Thus $\chi=\frac{P}{P_{o}}$ is the coefficient which reflects the variations in energy power from deep waters to the breaking point.

\subsection{Wave height and local water deep at breaking point}

Kaminsky and Kraus, (1993) and Sabatier, (2001) after conducting a comparative study based on an analysis of previous studies (409 cases) covering a wide range of wave cambers and beach slopes, propose to use for $\tan \beta \leq 0,1$ the breaking index below that takes into account Irraben number $\left(\xi=\tan \beta \sqrt{\frac{L_{o}}{H_{o}}}\right)$ (Tsai and al., 2002)

$\gamma=\frac{H_{b}}{d_{b}}=1.2\left(\tan \beta \sqrt{\frac{L_{o}}{H_{o}}}\right)^{0,27}$

On the study site, $0.001<\tan \beta \leq 0.1$, this criterion is selected to determine the breaking point of the waves and we obtain.

$$
\left\{\begin{array}{l}
d_{b}=\frac{H_{o}^{0,908} L_{o}^{0,092}}{1,33(\tan \beta)^{0,216}} \\
H_{b}=0,903 H_{o}\left(\frac{L_{o}}{H_{o}}\right)^{0,227}(\tan \beta)^{0,054}
\end{array}\right.
$$

\section{Results and Discussion}

The curves in Figure 3 are the coefficients of variation of the wavelength, of height, of the phase and group velocities and energy power of swell in the Gulf of Guinea in Benin.

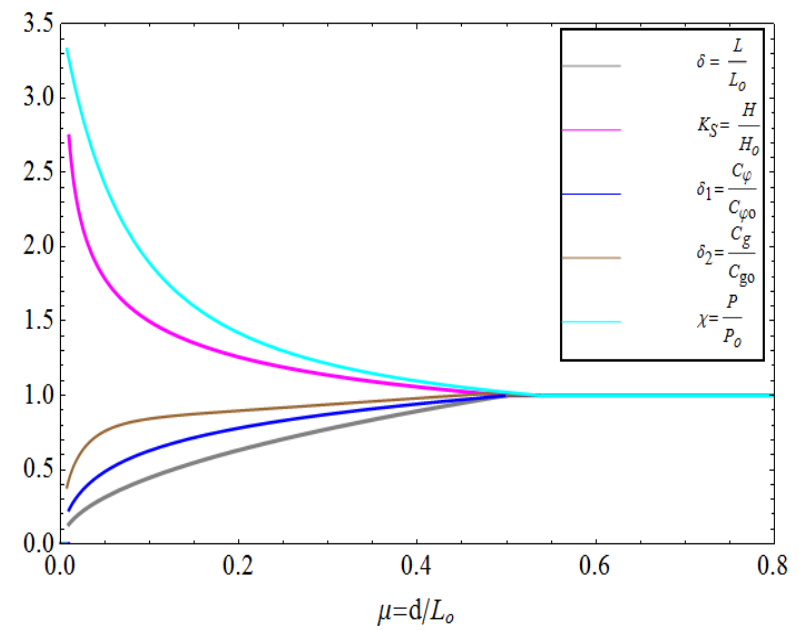

Figure 3. Coefficients of variations of wave characteristics parameters in the Gulf of Guinea in Benin.

All curves in Figure 3 show that all wave parameters in deep waters, apart from any obstacle, are constant.
The curve $K_{s}=\frac{H}{H_{O}}$ represents the variation of the height in deep waters and in the shoaling zone. It is constant in deep waters $\left(K_{S} \approx 1\right)$ and believes strictly in the shoaling zone $\left(1 \leq K_{s} \leq 2.8\right)$ and this amplification stops at the breaking point. The peak to valley wave's height, constant in deep waters is strictly increasing in the shoaling zone. This height, which believes strictly when the local water depth decreases, remains proportional to $\left(d^{-1 / 4}\right)$ : this result coincides with the results obtained for the shoaling of subharmonic gravity waves (Battjes et al. 2004).

Curves $\delta=\frac{L}{L_{o}}, \quad \delta_{1}=\frac{C_{\varphi}}{C_{\varphi_{o}}}$ and $\delta_{2}=\frac{C_{g}}{C_{g_{o}}}$ decreases in shoaling zone when the local water depth decreases.

But the decrease was more pronounced in the case $\delta$ and low for $\delta_{2}$. In the coastal zone of the Gulf of Guinea in Cotonou, the wavelength of swell decreases when the local water depth decreases and remains proportional to the square root of the latter $(L \sim \sqrt{d})$.

The evolution of the curve $\delta_{2}$ shows that the group velocity decreases strictly in the shoaling zone. This result justifies the fact that the speed of a system subject to energy dissipation cannot grow

Variations of $\delta_{1}$ indicate that the phase velocity decreases as the waves move towards the shore. The phase and group velocities of swells in the shoaling zone in Cotonou decrease when the local water depth decreases. But in this area, the group velocity is always greater

The curve $\chi=\frac{P}{P_{o}}$ reflects variations in wave energy power. In deep waters, this curve shows that this quantity is constant. In shoaling zone, it is amplified when the local water depth decreases and this amplification stops at the breaking point. It shows that $1 \leq \chi \leq 3.5$ : Energy power can be amplified 3.5 times before the breaking point.

The following diagram in Figure 4 shows the variations in the available energy power waves in deep waters and in the shoaling zone on the Benin coast.

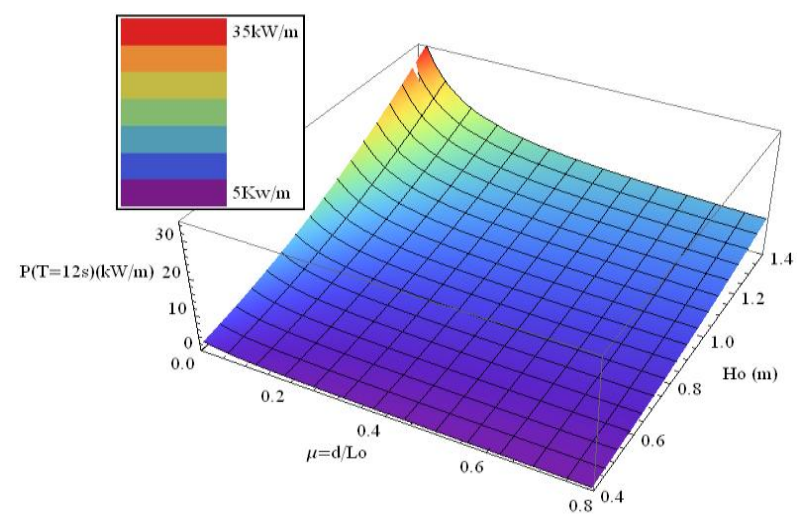

Figure 4. Variations in wave energy power in the coastal zone of Benin 
The evolution of the diagram in Figure 4 shows that the energy available power of the waves in the coastal zone of Benin is amplified when the local water depth decreases to the breaking point. In deep waters, the power varies between. $5 \mathrm{~kW} / \mathrm{m}$ and $12 \mathrm{~kW} / \mathrm{m}$ and approximately. Under the effect of shoaling, the energy power and believes and oscillates between $10 \mathrm{kW/}$ $m$ and $35 \mathrm{~kW} / \mathrm{m}$ : These swells therefore become more energetic when the seabed slope increases.

The curves in Figure 5 herein after, show the evolution of the local water depth $d_{b}$ and the wave height $H_{b}$ up to the bathymetric breaking point depending on the wave's period $\mathrm{T}$ one hand and depending on the height of the swells off the other.
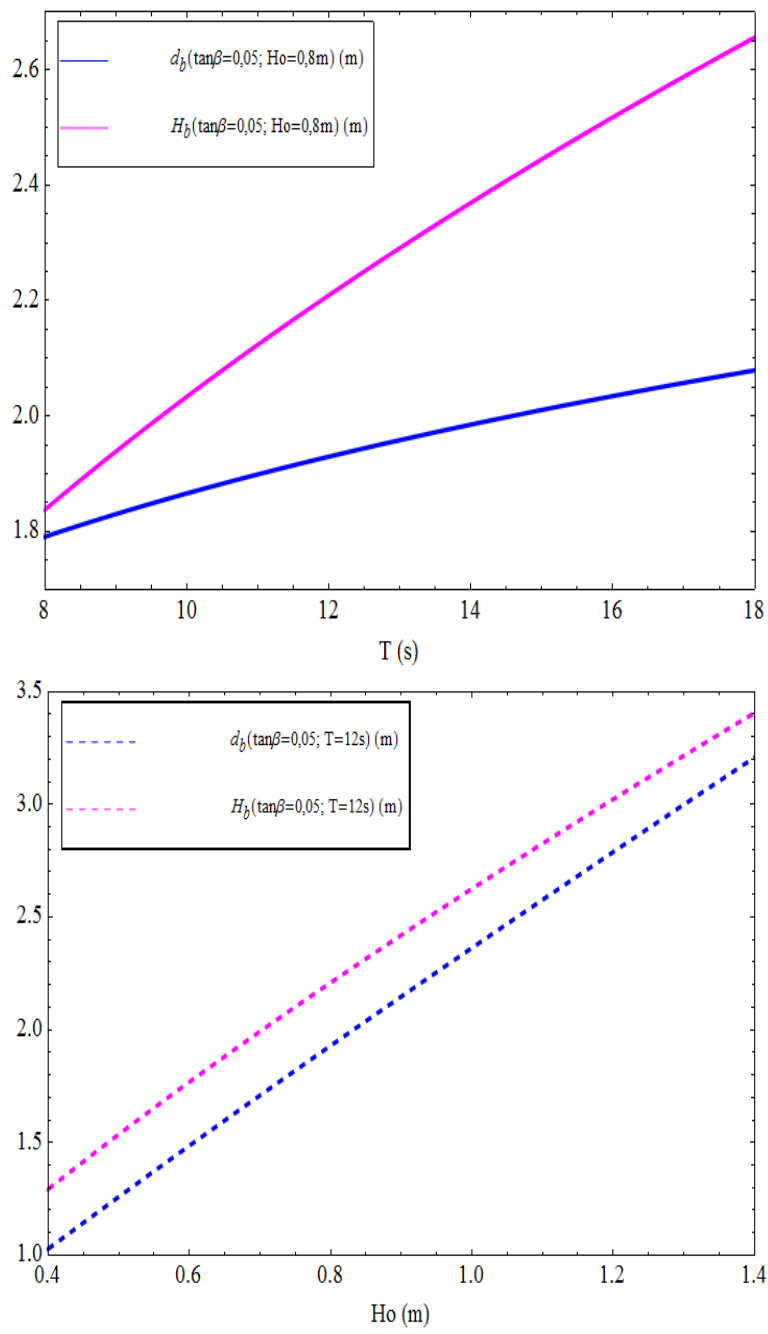

Figure 5. Variations of local water depth $d_{b}$ and wave height $H_{b}$ at the breaking point in $2 \mathrm{D}$ according $\mathrm{T}$ or $\mathrm{H}_{\mathrm{o}}$

As to diagrams in Figure 6, they show respectively, for a seabed slope $\tan \beta=0.05$, changes in the local water depth $d_{b}$ and those of the height $H_{b}$ of waves at the bathymetric breaking point.
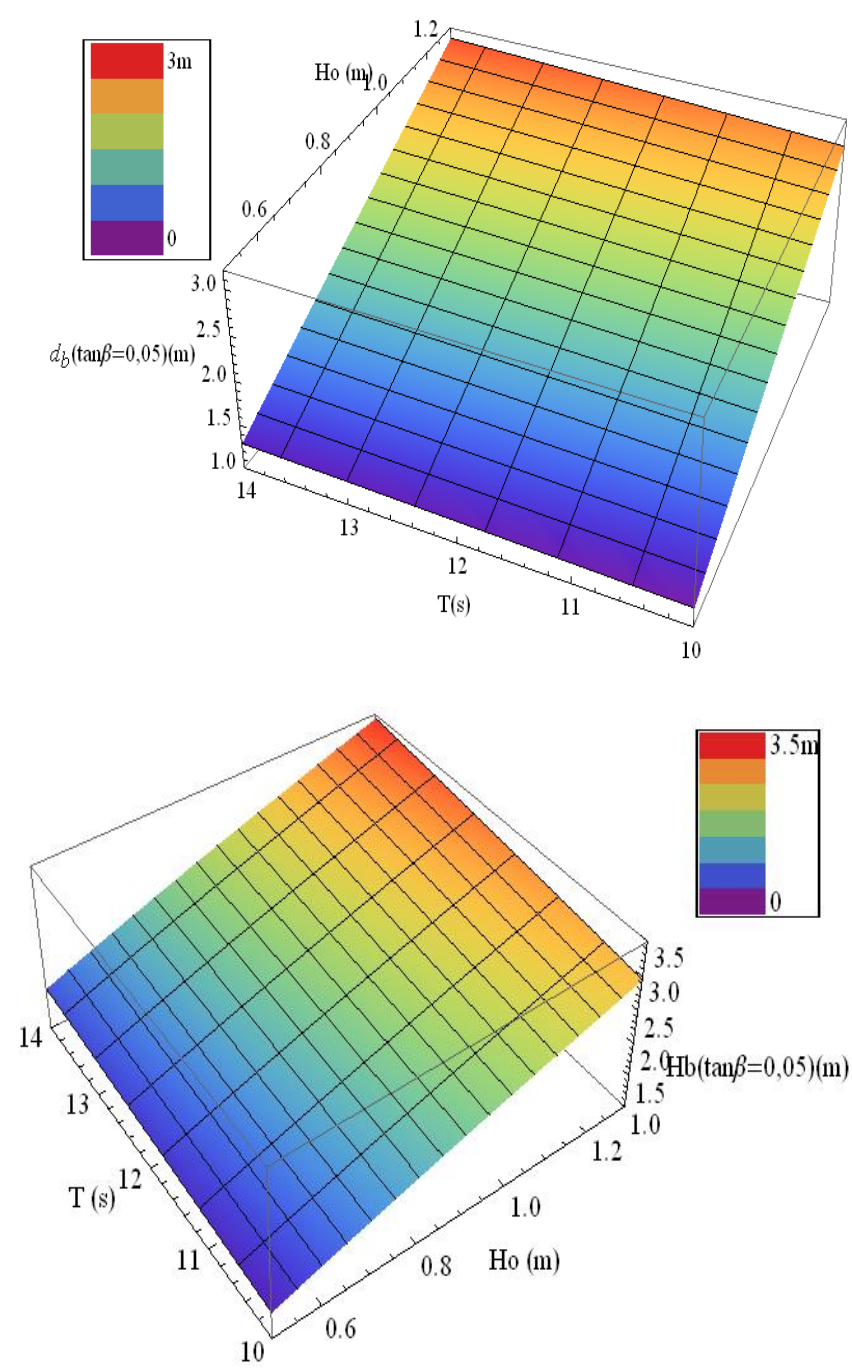

Figure 6. Variations of local water depth $\mathrm{d}_{\mathrm{b}}$ and wave height $\mathrm{H}_{\mathrm{b}}$ at the breaking point in $3 \mathrm{D}$ according $\mathrm{T}$ and $\mathrm{H}_{\mathrm{o}}$

The curves in Figure 5 and Figure 6 diagrams obtained from the results of the theory of Boussinesq and breaking criterion Kaminsky and Krauss (1993) show that the local water depth and height swell to the breaking point varies depending on the slope of the seabed, period and wave height in deep waters. Greater the slope, the less great is the local water depth at the point breaking and greater is the height of the waves at this point. These results show that, in the coastal zone of the Gulf of Guinea in Cotonou on bathymetric wave breaking occurs at a position where the local water depth varies between $1 m$ and $3.2 m\left(1 m \leq d_{b} \leq 3.2 \mathrm{~m}\right)$ when $0.4 m \leq H_{o} \leq 1.4 m$ and $10 s \leq T \leq 14 s$ : greater the slope, the greater the local water depth at breaking point decreases. Under the same conditions, the wave height at breaking point varies between $1.2 \mathrm{~m}$ and $2.8 \mathrm{~m}$ approximately $\left(1.2 \mathrm{~m} \leq H_{b} \leq 2.8 \mathrm{~m}\right)$. These results are very similar measurements performed $\left(0.8 m \leq d_{b} \leq 3 m\right.$ and $\left.1 m \leq H_{b} \leq 2.7 m\right)$ and justify the appropriateness of breaking criterion is chosen. 
Citation: Houékpohéha M. A., Kounouhéwa B. B., Hounsou J. T., Tokpohozin B. N, Hounguèvou J. V., and Awanou C. N. (2015). Variations of Wave Energy Power in Shoaling Zone of Benin Coastal Zone. Int. Journal of Renewable Energy Development, 4(1), 64-71, doi:10.14710/ijred.4.1.64-71

$P$ a g e 169

Figure 7 diagrams below; reflect variations in the vertical elevation of the free ocean surface according to the local water depth $d=\mu L_{o}$ and slope $\tan \beta=0,05$ of the seabed.

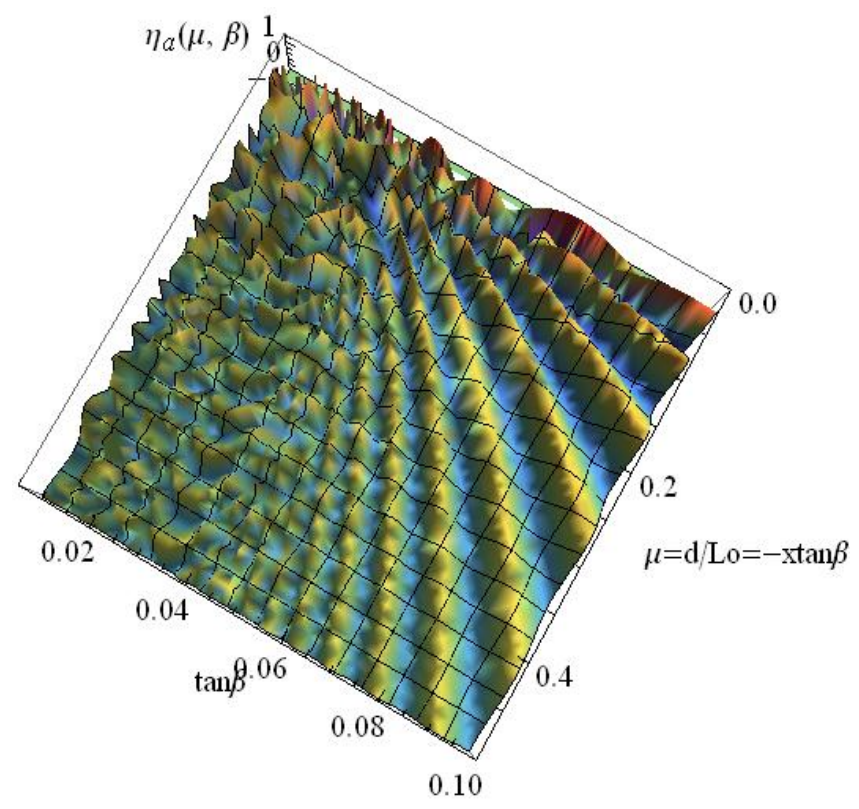

Aerial view

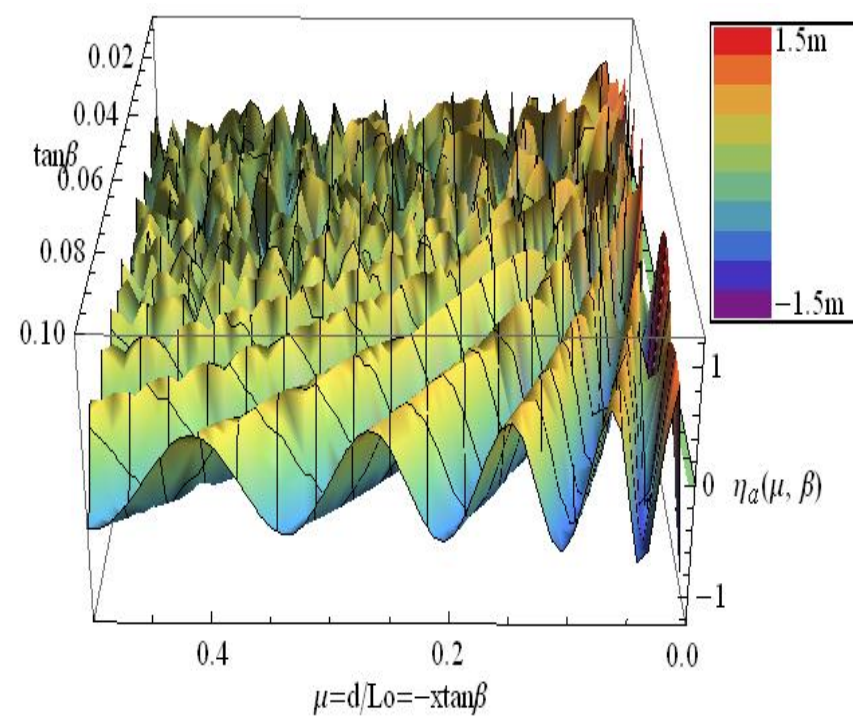

Longitudinal view

Figure 7. Vertical elevation of the sea surface in the shoaling zone in 3D according to the local water depth $\mu=\mathrm{d} / \mathrm{L}_{\mathrm{o}}$ and the seabed slope $\beta$

Their variations confirm:

- The consistency of the various parameters in deep waters.
- Amplification of the peak to valley height of waves in shoaling zone disrupted the seabed.

- The decrease or contraction of the wavelength caused by the slope of the seabed.

- The fluctuating and randomness of the deformation of the surface of the ocean, which is observed on the coast of Benin, even in the absence of a local wind. These results indicate that the variability of slope of the seabed helps randomness of oscillations at the ocean surface in the coastal zone.

From this work, it emerges that in the coastal zone of Benin (in the Gulf of Guinea), the swells become very energetic when they move towards the coast. Their bathymetric breaking which comes very close to the coastline and coastal ground geology in Cotonou (noncohesive sediments: sandy soil) are the major causes of coastal erosion which is observed along this site.

\section{Conclusion}

In the Gulf of Guinea at Cotonou, the waves are regular and have a constant height $H_{o}=0.8 \mathrm{~m}$ and a mean period $T=12 \mathrm{~s}$ in the deep waters. In the coastal zone, the perturbation effect of the seabed shoaling causes their up to breaking point. These waves become very energetic in this area; their height is amplified and is proportional to $\left(d^{-1 / 4}\right)$. Under the effect of shoaling, the wave energy power is amplified when the local water depth decreases and can vary between $10 \mathrm{~kW} / \mathrm{m}$ and $35 \mathrm{~kW} / \mathrm{m}$. At break point, the maximum height reached by the waves varies between $1.2 \mathrm{~m} \leq$ $H_{b} \leq 2.3 \mathrm{~m}$. Their depth breaking occurs at a position where the local water depth $d_{b}$, which oscillates between $1 m \leq d_{b} \leq 3.2 m$ according to the value of the seabed slope, is very close to the coastline. This breaking is a brutal energy discharge that induces and increases the phenomenon of coastal erosion. Benin and therefore the sub-region have two advantages to be gained from converting this energy:

- Curbing the cyclic crisis of electrical energy in the sub-region;

- Mitigate Coastal Erosion in the Gulf of Guinea by the absorption of sudden energetic discharge of waves thanks to various conversion systems of marine energy.

\section{Acknowledgments}

We sincerely thank the authorities of Halieutic and Oceanographic Research Center of Benin (CRHOB) Current IRHOB (Institute of Benin for Halieutic and Oceanographic Research) for graciously agreed to put at our disposal the wave data that we have used and without them we could not achieve the realization of this work. 


\section{Nomenclature of parameters}

$\eta(x, t) \quad$ : Vertical ocean surface elevation (m)

$H \quad$ : Wave peak to valley height (amplitude) $(\mathrm{m})$

$T \quad$ : Wave period $(s)$

$L \quad$ : Wavelength $(m)$

$C_{\varphi} \quad$ : Wave phase velocity $(\mathrm{m} / \mathrm{s})$

$C_{g} \quad$ : Wave phase velocity $(\mathrm{m} / \mathrm{s})$

$d \quad:$ Local water deep $(m)$

$\tan \beta \quad$ : Seabed slope

$\mu=\frac{d}{L_{o}} \quad$ : Dispersion parameter of waves train

$\varepsilon=\frac{2 H}{d} \quad:$ Nonlinearity parameter

$P \quad$ : Wave energy power $\left(W / m^{2}\right)$

$\delta=\frac{L}{L_{O}} \quad$ : Coefficient of wavelength variations

$\delta_{1}=\frac{C_{\varphi}}{C_{\varphi_{o}}}$ : Coefficient of phase velocity variations

$\delta_{2}=\frac{C_{g}}{C_{g_{o}}}$ : Coefficient of group velocity variations

$K_{S}=\frac{H}{H_{o}}$ : Coefficient of wave height variations (shoaling coefficient)

$\chi=\frac{P}{P_{o}} \quad$ : Coefficient of wave energy power variations

$H_{b} \quad$ : Wave height at breaking point $(\mathrm{m})$

$d_{b} \quad$ : Local water deep at breaking point $(m)$

\section{References}

Abbasov I. B. (2012) Numerical Simulation of Nonlinear Surface Gravity Waves Transformation under Shallow-Water Conditions. Applied Mathematics, vol 3, pp 135-141,

Ardakani A. and Bridges. J. (2010) Shallow-water sloshing in rotating vessels undergoing prescribed rigid-body motion in two dimensions. Department of Mathematics / University of Surrey / Guildford GU2 7XH UK, pp 1-48.

Astier J. (2014). « Morpho dynamique de la zone de "Swash": étude en canal à houle par une méthode de stéréoscopie optique ». Université de Toulouse, avril 2014 : Ecole doctorale: Sciences de l'Univers de l'Environnement et de l'Espace (SDU2E) "Hydrologie, Hydrochimie, Sols, Environnement ».

Babarit A., Rousset J-M., Mouslim H., Aubry J. Ben Ahmed H. et Multon B. (2009) La récupération de l'énergie de la houle, Partie 1 : Caractérisation de la ressource et bases de l'hydrodynamique. revue 3EI, pp.17-25.

Battjes J. A., Bakkenes H. J., JanssenT. T. and van Dongeren A. R. (2004) Shoaling of subharmonic gravity waves. Journal of Geophysical Research, vol. 109, C02009, pp 1-5, doi: 10.1029/2003JC001863.

Bellec S., Colin M. and Ricchiuto M. (2013) Sur des Modèles Asymptotiques en Océanographie. Bacchus Teams-Projects, Research Report n 8361 - pp 1-39, [hal-00860438, v1].

Bird E. C. F. (1985). "Coastline changes". A global review, Chichester, John Wiley \& Sons, A Wiley - Interscience publication, $219 \mathrm{p}$.

Bonneton P. (2003). La dynamique non linéaire des vagues en zone de Surf interne . RFGC - 7 / 2003. Génie côtier, page 1061 - 1076.

Bonneton P. (2001) Note sur la propagation des vagues en zone de surf interne, C. R. Acad. Sci. Paris, vol 329, Serie IIb, p. 27-33.

Catalan P. A. and Haller M. C. (2008) "Remote sensing of breaking wave phase speeds with application to non-linear depth inversions", Coastal Engineering, vol 55, pp 93 - 111,

Chazel F. (2007) "Influence de la topographie sur les ondes de surfaces", Thèse $\mathrm{N}^{\circ} \mathrm{d}$ 'ordre 3436 de l'Université de Bordeaux I, (Ecole doctorale de Mathématiques et Informatiques), pp 1-139.
Degbe C. G. E., Oyede L. M. et Laïbi R. A. (2010) "Mise en valeur des zones littorales et risques environnementaux : quelles stratégies pour un développement durable en Afrique de l'Ouest et du Centre", International Dredging Days, Libreville (Gabon), 1-12.

Didenkulova I. I. and Pelnovsky E. N. (2008) "Run-up of long wave on a Beach: The influence of the incident wave form", Oceanologiya (Marine Physics), Vol. 48, 5-10.

Fenton J. D. (1990) "Nonlinear Wave Theories", the Sea, Vol.9: Ocean Engineering Science, Eds. B. Le Méhauté and D.M. Hanes, Wiley, New York.

Galan A., Simarro G., Orfila A., Simarro J. and Liu P. L.-F. (2012) "A Fully Nonlinear Model for Water Wave Propagation from Deep to Shallow Waters", Journal of Waterway, Port, Coastal, and Ocean Engineering, Vol. 138, No. 5, CASCE, ISSN 0733-950X/2012/5-110

Gonzalez L. T. (2009) "Calculs exactes des paramètres des principales théories non linéaires des vagues et proposition d'un outil simplifié de calculs", Thesis $\mathrm{N}^{\circ}: 0 / 1 / \mathrm{A} / \mathrm{I} / \mathrm{X} / 3 / 0 / 1 / 0 / 3$ of Faculty of Graduate Studies at the University of Laval Québec (Genie Civil), 1-251.

Houekpoheha A. M.; Kounouhewa B. B.; Tokpohozin N. B. and Awanou C. N. (2014) "Estimation de la puissance énergétique éolienne à partir de la distribution de Weibull sur la côte béninoise à Cotonou dans le Golfe de Guinée", Revue des Energies Renouvelables, Vol. $17 \mathrm{~N}^{\circ} 3,489-495$.

Hsu T.-W., Lin T.-Y., Wen C.-C. And Ou S._H. (2006) "A complementary mild-slope equation derived using higher-order depth function for waves obliquely propagating on sloping bottom", Phys. Fluids 18(8), 087106, 1-14, (C) American Institute of Physics.

Kounouhewa B. B.; Houekpoheha A. M.; Tokpohozin N. B.; Awanou C. N. and Chabi-Orou B. J. (2014) "Simulation of swell energy power in Autonomous Port of Cotonou", J. Rech. Sci. Univ. Lomé (Togo), 2014, Serie E, 16(2) : 183-193

Kounouhewa B. B.; Tokpohozin N. B.; Houekpoheha A. M.; Awanou C. N. and Chabi-Orou B. J. (2014) "Simulation of the energy power of the internal marine currents at Port of Cotonou in Benin and its impact on the seabed", J. Rech. Sci. Univ. Lomé (Togo), Serie E, 16(3): 175-185

Lannes D. and Bonneton P. (2009), "Derivation of asymptotic twodimensional time-dependent equations for surface water wave propagation", Physics of Fluids DOI: 10.1063/ 1.3053183, 21, $016601,1-9$.

Panchang G. V., Pearce R. B., Wei G. an,d Cushman-Roisin B. (1991) "Solution of the mild-slope wave problem by iteration", Applied Ocean Research, 1991, Vol 13, N 4 .

Sabatier F. (2001) "Fonctionnement et Dynamiques morphosédimentaires du littoral du Delta du Rhone", Thesis $\mathrm{N}^{\circ}$ : 0/1/A/I/X/3/0/1/0/3 of AIX-Marseille II University, (Doctoral School of the Faculty of Science and Technology of Saint Jerome).

Senechal N., Bonneton B. and Dupuis H. (2004) "Paramétrisation de l'énergie des vagues en zone de surf interne: Profil de plage " plane » et profil de plage à barres", Revue Paralia, VIII National Days Civil Engineering - Coastal Engineering, Compiègne

Senechal N. (200 3) "Etude de la propagation des vagues au-dessus d'une bathymétrie complexe en zone de surf', thesis of Bordeaux I University, $\mathrm{N}^{\circ}: 2759,1-288$.

Shengcheng J. (2013) "Simulation 3D des ondes de batillage générées par le passage des bateaux et des processus associée de transport de sédiments", Thesis, University of Technology of Compiègne (UTC), D2068, 1-153.

Tissier M. (2011) "Etude numérique de la transformation des vagues en zone littorale, de la zone de levée aux zones de surf et de jet de rive", Thesis $\mathrm{N}^{\circ}: 4437$ of University of Bordeaux I, (Graduate School Science and Environments), 1-193.

Tsai C-P., Chenh-B. and Huang M-J. (2002) "Wave Shoaling on Steep Slopes and Breaking Criteria.", Kitakyushu, Japan, Copyright (C) 2002 by The International Society of Offshore and Polar Engineers ISBN 1-880653-58-3 (Set); ISSN 1098-6189 (Set), 617621

Tokpohozin N. B., Kounouhéwa B., Avossevou G. Y. H., Houékpohéha M A., Awanou C. N. (2015). "Modelling of sediment movement in the 
Citation: Houékpohéha M. A., Kounouhéwa B. B., Hounsou J. T., Tokpohozin B. N, Hounguèvou J. V., and Awanou C. N. (2015). Variations of Wave Energy Power in Shoaling Zone of Benin Coastal Zone. Int. Journal of Renewable Energy Development, 4(1), 64-71, doi:10.14710/ijred.4.1.64-71

$\mathrm{P}$ a g e $\mid 71$

surf and swash zones". Acta Oceanologica Sinica, 34(2): 137-142, doi: $10.1007 / \mathrm{s} 13131-015-0610-2$

Umeyama M. (2010) "Eulerian-Lagrangian analysis for particle velocities and trajectories in a pure wave motion using particle image velocimetry", Mathematical, Physical and Engineering sciences, doi: 10.1098/rsta.2011.0450.

Webster W. C., Duan W. and Zhao B. (2011) "Green-Naghdi Theory, Part A: Green-Naghdi (GN) Equations for Shallow Water Waves", J. Marine Sci. Appl., 10, 253-258, DOI: 10.1007/s11804-011-1066-1

Wu J. and Chen B., 2003. Unsteady ship waves in shallow water of varying depth based on Green-Naghdi equation, Ocean Engineering, 30, 1899-1913.

Zou Q., Hay A. E. and Bowen J. A. (2003) "Vertical structure of surface gravity waves propagating over a sloping seabed: Theory and field measurements". Journal of Geophysical Research 108 (C8, 3265), doi: 10.1029/2002JC001432, 21.1-21.15. 